\title{
Planning for Sustainable Water Supply through Partnership Approach in Wukari Town, Taraba State of Nigeria
}

\author{
Hassan Tsenbeya Ishaku ${ }^{1}$, Mohammed Abubakar Husain ${ }^{2}$, Fabian Mazawuje Dama ${ }^{2}$, \\ Ambrose Audu Zemba ${ }^{3}$, Ajayi Abayomi Peters ${ }^{2}$ \\ ${ }^{1}$ Department of Urban and Regional Planning, Universiti Teknologi Malaysia, Johor, Malaysia \\ ${ }^{2}$ Department of Urban and Regional Planning, Federal University of Technology, Yola, Nigeria \\ ${ }^{3}$ Department of Geography, Federal University of Technology, Yola, Nigeria \\ E-mail: htishaku123@gmail.com \\ Received July 28, 2010; revised August 18, 2010; accepted August 25, 2010
}

\begin{abstract}
It has been observed that government resources and interventions towards sustaining water supply in Wukari town have been insufficient. The result has been constant water crisis and shortages over the years. The objective of this paper is to explore the possibility of partnering for sustainable water provision, to identify potential partners and to propose an appropriate partnership framework. Two hundred and seventy-five (275) questionnaires were administered in the three (3) wards of the town from where respondents were drawn at random. Findings revealed that the centralized system of water management, the location of Wukari on a basement rock and the scarcity of state financial resources are some of the greatest obstacles to sustainable water supply. However, about $(90 \%)$ of the respondents are willing to collaborate with other stakeholders while the community members are ready to provide land and labor for the partnership arrangement. This study recommends a paradigm shift from the centralized water management to a partnership approach between service providers, recipients of services and other related stakeholders
\end{abstract}

Keywords: Planning, Sustainable Water Supply, Water Scarcity, Partnership Approach

\section{Introduction}

The World Health Organization [1] reported that the provision of potable water to an estimated one billion population who lack access to it remains one of the foremost challenges of human development today. For close to two decades, donors and leaders in developing countries have devoted public resources and leveraged private funds to construct improved water systems for urban and rural areas. While coverage rates is said to have improved over the years, growth in rural service has lagged behind compared to higher percentage of urban residents in developing countries who have gained access to better services. Currently, 1.2 billion people lack access to safe water sources. Nearly 2 billion people live with water scarcity, and this number is expected to rise to 4 billion by 2025 , unless radical reforms emerge. Reports from development agencies, governments, water commissions, and research institutes continually point to an impending water crisis. These agencies also point to the water crisis arising from mismanagement not an absolute scarcity problem. Thus, improving current water provisions and avoiding a crisis of availability with the entire human suffering is possible. The message highlighted by various international efforts is that sub-optimal management of water is not an option if sustainable development is to be achieved.

M. Jacqueline [2] stated that in most developing countries, the dramatic pace of demographic, economic and social changes severely overburdens the capacity of the local authorities to provide urgently needed infrastructure services. The challenge of providing adequate services can not be met through investment in technical facilities alone; and the needs and problems themselves are evolving too rapidly. In these circumstances, service provision depends very much on efficient organization of service delivery processes and the best possible use of available material and human resources. This involves 
mainly the issue of management which calls for cooperation between government agencies and infrastructure users as well as private sector actors.

Government must have the capacity to collaborate with recipients of service and related stakeholder to manage water infrastructure effectively and in a sustainable manner. Proponents of partnerships have often appealed to financial gains, cost reduction, efficiency gains, environmental compliance, human resource development and increased services which have followed private sector engagement. While opponents of partnerships have appealed to price increase, imbalance of power, labor disputes, inequalities environmental damage, and increased risks associated with private sector participation in water services. The aim of the partnership is to demonstrate how the private sector and the government can work together to deliver real and sustainable benefits of development for all. This approach argues that no government can afford to work in isolation. This means that partnerships can only complement and do not supplement governmental commitments. One of the ideals principles is the need to designate specific roles to individual or groups of potential partners based on previous similar projects or estimated financial potentialities.

P. Schubeler [3] argued that the partnership approach consists of a number of general principles that are designed to overcome the limitations of the traditional urban administration and the management of service delivery. It widens the scope of the actors involved in the provision of services to include urban infrastructure services. The stakeholders involved in the process include those whose interests are affected, those who posses relevant information and expertise and those who control and allocate resources. The partnership approach calls for an appropriate organizational basis for partners. It calls for a clear division of task in line with the interest and capabilities of each partner. The real benefits of participation derive not only from cost reduction and from resource mobilization during implementation of projects, but also from a more effective targeting of projects that measures the real needs of the people.

Although partnership is widely advocated for urban service delivery both in developed and developing countries, the concept has not been prominent in Nigeria. Most of the urban services are directly or indirectly planned and implemented by government through its various agencies. C. Shaw [4] stated that partnership aim at demonstrating how the private sector, civil society and the government can work together and to deliver real and sustainable benefits of development for all. This approach recognizes the strength and capabilities of different organization and to build partnership and network accordingly at the local level. The important element of this approach is that all partners act upon their different strengths-complementary resources, knowledge and skills to jointly address the complexities surrounding social, environmental and economic development.

Providing safe drinking water is a task so complex that neither the public nor the private sector can achieve it alone. The fact lies in large scale private sector participation in the provision of a much needed urban service such as water. Applying the principles of partnership will increase the potentials for both domestic and international private finance. To adequately understand the conceptual issues raised in this paper, partnership as applied in legal terms refers to an organization of two or more persons who have agreed to combine their labor, property and skill or some or all of them for the purpose of engaging in a lawful business and sharing the profits and loses between them. The parties forming such an association are known as partners.

\subsection{Problem Investigated}

Various studies [5-7] attributed water scarcity to distribution systems, technical problems and lack of adequate financial commitment from the part of the government. Other studies, A. Faniran and Y. Abdul $[8,9]$ noted that water scarcity is due to inadequate knowledge about available water resources at all levels of planning and climatic changes. There is a growing realization in many developing countries that government provision of water services has been inadequate as publicly operated water supplies exposes residents to disease attacks despite the substantial efforts to improve the quality and coverage of service; one quarter of the urban population is not connected to public water system. However, private sector participation in water supply services was advocated as a way out of the water predicament. But the rural communities can not afford the high rates of water services charged by the private sector due to their low income as peasant farmers.

J. Saghir [10] stated that during the 1990s there was a wide spread expectations that the private sector would have a critical role to play in improving access to water services because of its know how, efficiency and investment capitals. However, in recent years many international operators have been disengaging rather than increasing their involvement in most developing countries. Various factors are responsible for this such as political opposition from civil society, contractual disputes between government and private operators and unclear legal, policy and institutional framework. The international private operators perceive their involvement in water sector as carrying increased risk and have become more cautious in entering any contractual arrangement, particularly if it involves financial commitment. This historical governance structures range from fully privatized 
systems to public-private arrangements to public systems. In the light the problems in the water sector, public-private partnerships have been increasingly advocated and adopted in most parts of the world.

\section{Methods}

The objectives of this study are two folds: 1) to identify the partners and assess their roles in Wukari water supply, and 2) to propose an appropriate framework for effective water delivery in Wukari town. While the research questions which this study seeks to provide answers to include a) what is the percentage of households with or without access to safe water supply, b) what is the capacity of involvement of resident in water service delivery and c) is partnership the right way to improve water supply?

Primary data on the accessibility to water supply by households and willingness to pay for water bills were collected. For the households' (water users), discussion centered on their water supply sources, adequacy, how water was obtained, time spent in obtaining water, distance of water source from home, water storage facilities in use. Secondary data includes the data from published and unpublished literature on water supply was obtained from Federal Ministry of Water Resources. FMWR [11] and the Nigeria Population Commission NPC Official Result [12] etc. The secondary data from these agencies included budgetary allocations for urban water supply, the costs of various water facilities provided and cost recovery process, the actual population of each area delineated.

A structured questionnaire containing multi-choice answers was used as a guide for the interviews. This tool was used because of the possibility of its wide coverage as it helped to obtain data at a relatively short-term period. During the survey, questions attempted to elicit the following data on various sources of water supply, potential partners, socio-economic characteristics of respondents and willingness to pay for water bills among others.

A total of 275 persons were interviewed using the stratified random sampling. Wukari town was divided into three (3) wards from which respondent were drawn. These wards include Avyi ward (75) Hospital ward and (100) Puje ward (100). The population of Wukari in 2006 was put at 73,955 based on $3.0 \%$ growth rate; the estimated population for 2010 is expected to be 82,829 persons. This study utilized both descriptive and inferential statistics in data analysis. The descriptive statistic was used in summarizing the set of raw data into meaningful and concise information using percentages while inferential statistics enable generalization concerning the sampled population.

\section{Discussion of Results}

The variables used in this study are the factors that influence and determine water supply in Wukari town. These factors include existing and potential sources of water supply, household size, occupation of respondents and monthly income. Others include water per capita use, adequacy and willingness to pay for improved water services. Table 1 below shows the various sources of water supply in Wukari town.

At present the existing and reliable source of water supply is the well accounting for $46.6 \%$, although most of the wells do not yield water during the dry season. Water vending account for $37 \%$ it provides a wider coverage than well water. The water vendors either purchase water from borehole operators or fetch directly from the stream which is vulnerable to water borne diseases. The implication is that the partners will have to rely mostly on borehole using appropriate technology to get the required amount of water needed for the entire population.

Table 2 below shows that respondents within the household size of 6-10 account for $53.8 \%$. This can be used as basis for calculating the water per capita use based on the current population which can be also projected for future demand.

Table 3 shows that respondents whose monthly income falls between 11,000-N15, 000 accounts for 38.90 and those whose monthly income exceeds 16,000-N20, 000 accounts for $26.30 \%$ indicating that a larger percentage of the population earn above the government prescribed minimum wage for civil servants. Given the amount spent on water daily (N400-500), a subsidized water bill for the residents will strengthen participation in the water business.

Table 1. Sources of water supply in Wukari.

\begin{tabular}{|c|c|c|c|c|c|}
\hline \multirow{2}{*}{$\begin{array}{c}\text { Source of } \\
\text { water supply }\end{array}$} & \multicolumn{3}{|c|}{ Wards } & \multirow{2}{*}{ Total } & \multirow{2}{*}{$\begin{array}{c}\text { Per- } \\
\text { centage }\end{array}$} \\
\hline & Avyi & Hospital & Puje & & \\
\hline Borehole & 13 & 18 & 10 & 41 & 14.6 \\
\hline Well & 37 & 45 & 45 & 127 & 46.6 \\
\hline Stream & 1 & 2 & 2 & 5 & 1.80 \\
\hline $\begin{array}{l}\text { Water vend- } \\
\text { ing }\end{array}$ & 24 & 35 & 43 & 102 & 37.0 \\
\hline Total & 75 & 100 & 100 & 275 & 100 \\
\hline
\end{tabular}

Source: Fieldwork 2005

Table 2. Household size.

\begin{tabular}{cccccc}
\hline $\begin{array}{c}\text { House- } \\
\text { hold size }\end{array}$ & \multicolumn{3}{c}{ Wards } & Total & $\begin{array}{c}\text { Percent- } \\
\text { age }\end{array}$ \\
\cline { 2 - 4 } & Avyi & Hospital & Puje & & 3.27 \\
$1-5$ & 2 & 4 & 3 & 9 & 53.82 \\
$6-10$ & 33 & 49 & 66 & 148 & 29.09 \\
$11-15$ & 27 & 37 & 16 & 80 & 13.82 \\
Over 15 & 13 & 10 & 15 & 38 & 100 \\
Total & 75 & 100 & 100 & 275 & \\
\hline
\end{tabular}

Source: Fieldwork 2005 
Table 3. Monthly income.

\begin{tabular}{|c|c|c|c|c|c|}
\hline \multirow{2}{*}{$\begin{array}{l}\text { Monthly in- } \\
\text { come(Naira) }\end{array}$} & \multicolumn{3}{|c|}{ Wards } & \multirow{2}{*}{ Total } & \multirow{2}{*}{$\begin{array}{c}\text { Per- } \\
\text { centage }\end{array}$} \\
\hline & Avyi & Hospital & Puje & & \\
\hline $5,000-10,000$ & 10 & 10 & 8 & 28 & 10.18 \\
\hline $11000-15,000$ & 28 & 57 & 22 & 107 & 38.90 \\
\hline $16,000-20000$ & 32 & 6 & 37 & 75 & 27.30 \\
\hline $21,000-25000$ & 2 & 4 & 13 & 19 & 6.90 \\
\hline Over 25,000 & 3 & 23 & 20 & 46 & 16.72 \\
\hline Total & 75 & 100 & 100 & 275 & 100 \\
\hline
\end{tabular}

Source: Fieldwork 2005

Table 4. Occupation of respondents.

\begin{tabular}{cccccc}
\hline \multirow{2}{*}{ Occupation } & \multicolumn{3}{c}{ Wards } & \multirow{2}{*}{ Total } & Percentage \\
\cline { 2 - 4 } & Avyi & Hospital & Puje & & \\
\hline Civil servants & 22 & 68 & 52 & 142 & 51.00 \\
Businessmen & 30 & 23 & 21 & 74 & 26.00 \\
Farmers & 23 & 9 & 27 & 59 & 23.00 \\
Total & 75 & 100 & 100 & 275 & 100 \\
\hline
\end{tabular}

Source: Fieldwork 2005

Figure 1 below shows the monthly income of respondents. It is observed that respondents whose monthly income is $11,000-\mathrm{N} 15,000$ account for $38.90 \%$. This is above the government approved minimum wage of $\mathrm{N} 7$, 500 for the civil servants in the state.
Table 4 revealed that the civil servants accounts for $51 \%$ of the sampled population, while the businessmen and farmers accounts for 26 and $23 \%$ respectively. The implication of this is that the civil servants will be able to pay for improved service with ease as most of the farmers live in the villages. This means that cost recovery system will be effective as they are willing to pay for improved services.

Figure 2 shows the graphical representation of occupation status of respondents and the civil servants accounts for $51 \%$ of the total respondents while farmers represents $23 \%$ and mostly reside in the villages but commutes to the town at different times.

Table 5 gives the per capita water use by ward, it worthy to note that daily water requirements are not evenly distributed due to differences in occupational status and water per capita use by respondents. Thus, on the average 20 liters of water is needed by each person on daily basis for proper hygiene and wellbeing of individuals World Bank Group [13].

Table 6 shows the water adequacy level of respondents. About $71.63 \%$ of the respondents are of the view that their daily water supply is inadequate. This is attributed to the fact that the centralized system of water management by government has not been effective. On

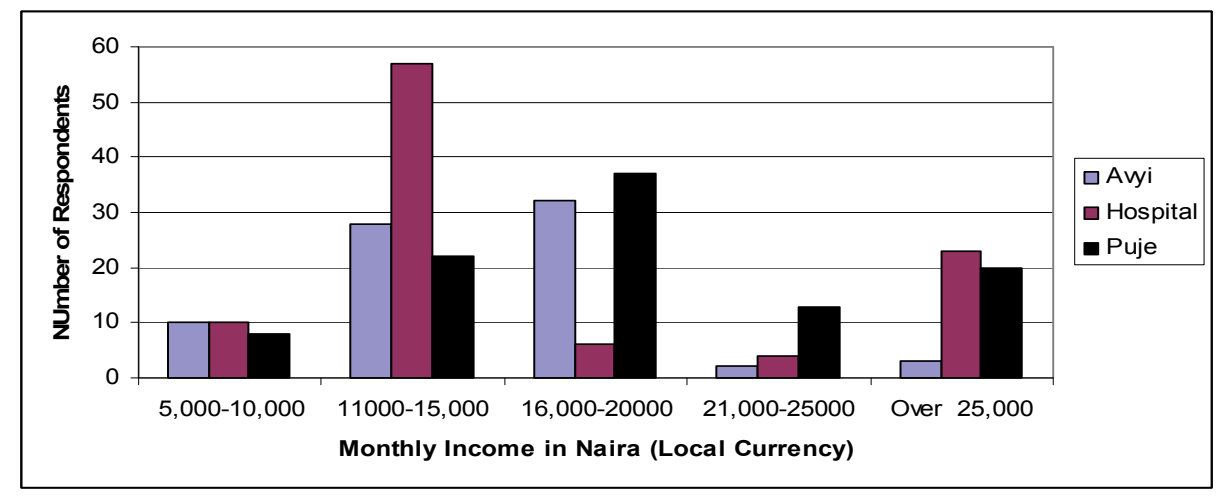

Note: $1.000 \mathrm{NGN}=154$ USD

Figure 1. Monthly income of respondent in each ward.

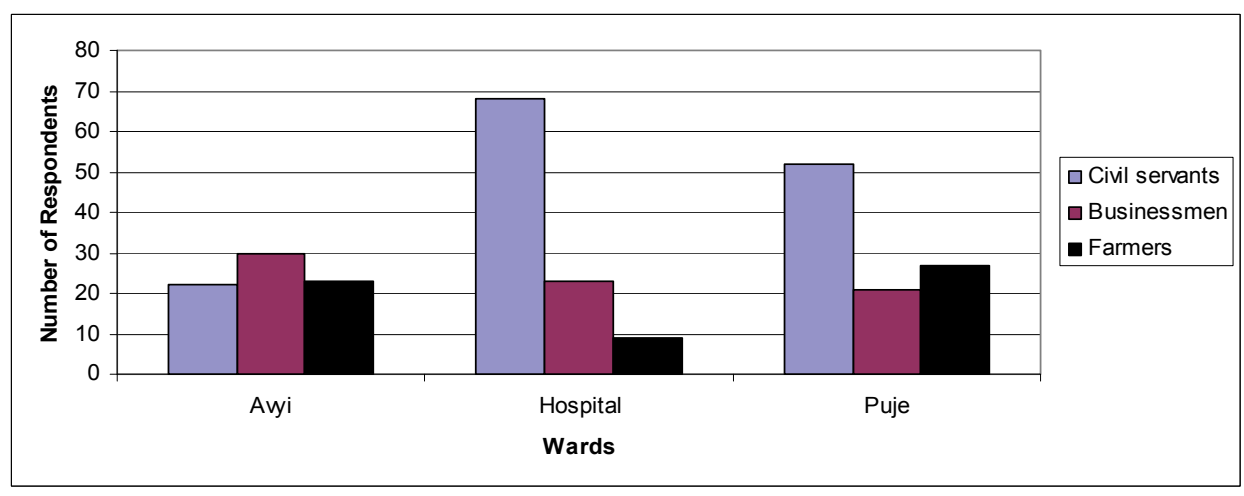

Figure 2. Occupation of respondents in each ward. 
Table 5. Water per capita use (Water per capita use in liters $(1$ jerry can $=20$ liters $)$.

\begin{tabular}{cccccc}
\hline & \multicolumn{3}{c}{ Wards } & Total & $\begin{array}{c}\text { Percent- } \\
\text { age }\end{array}$ \\
\cline { 2 - 4 } & Avyi & $\begin{array}{c}\text { Hospi- } \\
\text { tal }\end{array}$ & Puje & & \\
\hline 20 liters & 17 & 48 & 32 & 97 & 35.27 \\
21-30 liters & 37 & 34 & 59 & 130 & 47.27 \\
Above 30 liters & 21 & 18 & 9 & 48 & 17.46 \\
Total & 75 & 100 & 100 & 275 & 100 \\
\hline
\end{tabular}

Source: Fieldwork 2005

Table 6. Adequacy water supply in Wukari.

\begin{tabular}{cccccc}
\hline $\begin{array}{c}\text { Level of } \\
\text { ade- }\end{array}$ & \multicolumn{3}{c}{ Wards } & Total & $\begin{array}{c}\text { Percent- } \\
\text { age }\end{array}$ \\
\cline { 2 - 4 } quacy & Avyi & Hospital & Puje & & 78 \\
\hline Yes & 12 & 39 & 27 & 28.36 \\
No & 63 & 61 & 73 & 195 & 71.64 \\
Total & 75 & 100 & 100 & 275 & 100 \\
\hline
\end{tabular}

Table 7. Willingness to pay water for improved service.

\begin{tabular}{cccccc}
\hline willing- & \multicolumn{3}{c}{ Wards } & Total & $\begin{array}{c}\text { Per- } \\
\text { centage }\end{array}$ \\
\cline { 2 - 4 } & Avyi & Hospital & Puje & & 90.90 \\
\hline Willing & 71 & 93 & 86 & 250 & 90.45 \\
$\begin{array}{c}\text { Not } \\
\text { willing }\end{array}$ & - & 7 & 8 & 15 & 5.45 \\
$\begin{array}{c}\text { Unde- } \\
\text { cided }\end{array}$ & 4 & - & 6 & 10 & 3.65 \\
Total & 75 & 100 & 100 & 275 & 100 \\
\hline
\end{tabular}

the other hand, $28.36 \%$ agreed that their daily water requirement is adequate which may be attributed to the low household size or proximity to alternative water source.

Responses on the willingness to pay for improved water services were also collected. Table 7 revealed that over $90 \%$ of the respondents are willing to pay for the water bills. This does not automatically mean that partnership will flourish $100 \%$ but it will encourage the partners as they are most likely to benefit from their investment.

Figure 3 shows a graphical representation Table 7 willingness of respondents to pay for improved water service across the wards.

\section{Partnership Frame Work for Wukari Water Supply}

The important aspect of this study is to propose an effective partnership framework and machinery for the implementation that will translate these proposals for water supply into a reality. In view of the current state government dwindling financial resources which is reflected in its inability to tackle the water crisis for over 2 decades as well as growing demands for safe water supply, there is the need for an efficient arrangement which should reflect the participation of various consumers and service provider such as government agencies, private organizations, non-governmental organizations and community based organizations.

The responsibility of ensuring the enabling environment for the partnership to operate rest squarely with the government which need to provide the legal, fiscal and policy framework. However, role assignment becomes very necessary on the basis of previous similar projects or financial potentialities. Potential partners in Wukari water supply will involve the following stakeholders as shown in Figure 4.

\subsection{Taraba State Government}

The Taraba state government is to play a supervisory role involving institutional, fiscal and legal framework. The state government is to also install water facilities, undertake rehabilitation works, provide technical advice and above all provide funds.

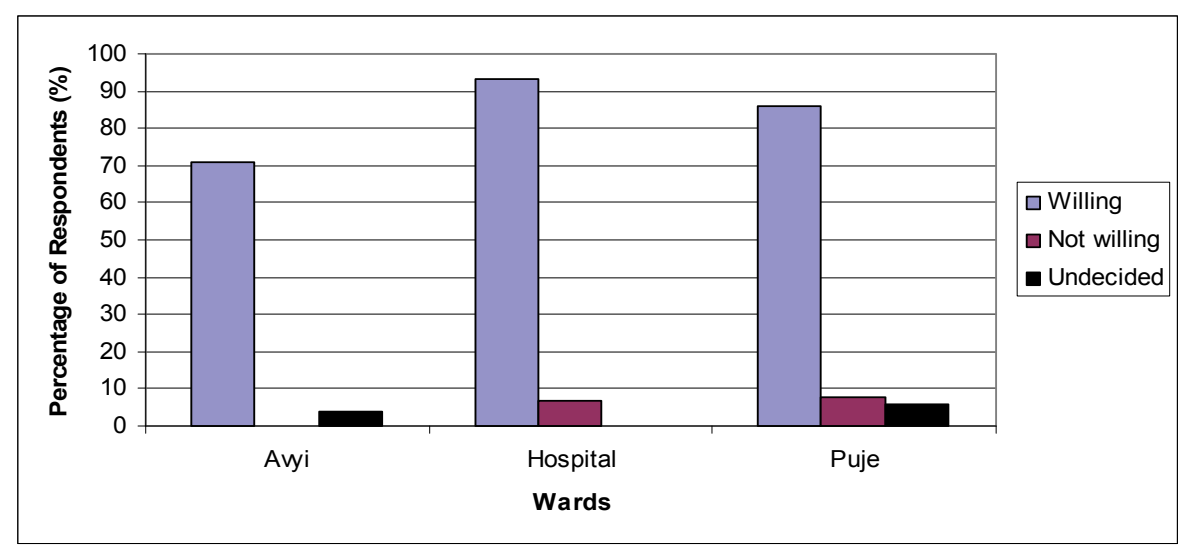

Figure 3. Percentage of willingness of Respondents per ward. 


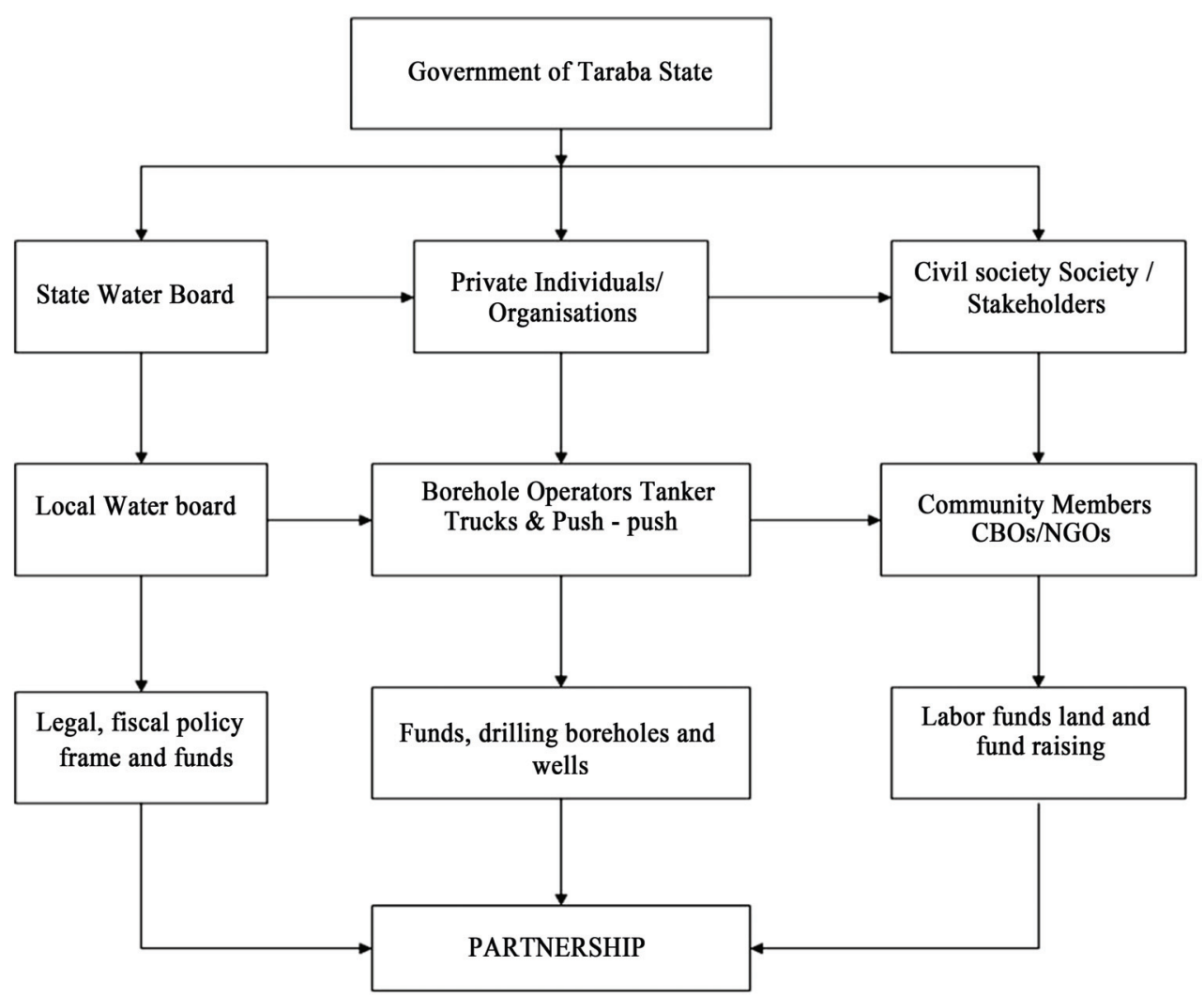

Figure 4. Partnership framework.

\subsection{Wukari Local Government Council}

The local government council is commonly referred to as the third tier of government will be responsible for operation and maintenance of water facilities, embark on awareness campaign, digging of additional sanitary wells and provide funds.

\subsection{Non-Governmental Organizations (NGO's)}

The non-governmental organizations though very few are potentially important in the partnership arrangement. They play a crucial role in facilitating communities in infrastructure development. They will provide free labor, technical advice, awareness campaign and raise funds

\subsection{Community Based Organizations (CBOs)}

The main objective is to support the local development of infrastructure services and to enhance the community capacity to manage services. Because of this bottom-up approach, the local partners have a sense of ownership of development project and strongly committed to seeing through a successful conclusion. They are to provide labor, land and food during constructional works, drill well and borehole, raise funds and embark on awareness campaign in the various communities

\subsection{Private Sector}

The private sector refers to institutions, firms and individuals who may be active in many different aspects of infrastructure management but whose objective is to generate profit from their investment. These groups shall provide funds, drill boreholes, offer technical advice and the maintenance of water facilities

At this point, partnership requires the establishment and strengthening of participating mechanisms which will ensure that all voices are heard in identifying problems and priorities, setting goals and exercising legal rights in determining service standard, mobilizing resources and implementing policies and programs of water supply in Wukari. This cooperation will result in organization of specific forms of coordinating committees by the state government through the local government.

\section{Conclusions}

The water supply plant for Wukari town is located in Tsokundi about $25 \mathrm{~km}$ away from Wukari town. This plant was meant to generate 3400 cubic meter $(0.75$ million gallons) of water per day, although the water de- 
mand for the town was put at 7000 cubic meters (1.5 million gallons) per day. Dar-Alhandasah Consultant [14], this figure is far from being adequate for the estimated 59,955 people in 1996 and 73,955 in 2006 and estimated 82,829 persons in 2010 when compared with the national average per water supply of 63 and 21 liters per person per day for both urban and rural areas respectively.

The location of Wukari on a basement rock coupled with lack of funds and the centralized system of water management has significantly affected service delivery to the residents. This is evident in the fact that most taps have not had water for years. There is the need to undertake the geological survey to determine the aquifer and underground water recharge.

The treatment plant located in Tsokundi is usually heavily silted during the rainy season which adds to the total cost of treatment and hence the absence of tap water in the area. It is suggested that this plant be moved to river Ibi about $34 \mathrm{~km}$ which is not heavily silted and relatively maintains a higher volume of water during the dry season.

Another implication of the findings is that water vending constitutes the bulk of water source. This source has health related problems since the water is not usually treated before being sold to public.

\section{References}

[1] World Health Organization, Global Water Supply and Sanitation Assessment Joint Monitoring Program for Water Supply and Sanitation Series, 2000. www.who. int/water_sanitaion_health/monitoring/global/assess/en/

[2] M. Jacqueline, "Water Governance," In: J. C. Cutler, Ed. Encyclopedia of Earth, Washington D.C. Environmental Information Coalition, National Council for Science and Environment, 2008. http://www.eoearth.org/article/water_ governance27June2009.
[3] P. Schubeler, "Participation and Partnership in Urban Infrastructure Management," The World Bank, 1996. www.worldbank.org/wbi/sourcebook/sba/htm_cached.

[4] C. Shaw, "Tri-Sector Partnerships: How They Work?" The Department for International Development Magazine Issue 18 Second Quarter, The Lime house Group, 2003. www.developments.org.uk/search?Searchabletext=impro ved

[5] A. Akintola and B. Areola, "The Perennial Incidence of Water Scarcity in Ibadan Nigeria; the Way Forward," Spectrum Books Ltd, Ibadan, 1980.

[6] A. Aliyu, "Water Scarcity in Maiduguri Metropolis Problems and Prospects for Nigeria," Sabon-Dale Press, Awolowo Way, 1996.

[7] S. Lakhan, "Domestic Water in Northern Trinidad: Access, Collection and Quality," Florida, 2007. www.scribd. com/doc/19551153/Case-Study-Guide

[8] A. Faniran, "Strategies for Water Supply Design in Developing Countries. An Appropriate Technology," University Press, Benin, 1992.

[9] Y. Abdul, "Water Shortages in Damaturu. The Way forward for Solving Water Crisis in Desert Areas of Nigeria," Unpublished, 1997.

[10] J. Saghir, "Public -Private Partnerships in Water Supply and Sanitation," The World Bank OECD Global Forum on Sustainable Development, Paris Press Information/Paper Presentations, Recent Trends and Opportunities, 29-30 November 2006. www.oecd.org/.../html

[11] Federal Ministry of Water Resources, Federal Republic of Nigeria, Old Federal Secretariat Garki, Abuja, 2000. http://www.uneca.org/awich/Nigerian\%20Report. pdf.

[12] Nigeria Population Commission Official Result, "House and Population Census Figures," Bureau for National Statistics, Abuja, 2006. http://www.nigerianstat.gov.ng

[13] The World Bank Group, Annual Report on Access to Safe Water Supply in Developing Countries, 2004. http:// www.worldbank.org/depweb/

[14] Dar-Alhandasah Consultant, "Wukari Master Plan 19772007," Shairs and Partners, London, 1977. 